https://doi.org/10.30702/ujcvs/21.4512/EG054-3035

UDC 616.12-089.843-089.168+616.12-089.83-089.168]-042.2

Elif Erdogan ${ }^{1^{*}}$, MD, https://orcid.org/0000-0002-2206-9928

Gokhan Gokarslan², MD, https://orcid.org/0000-0003-1730-0993

Feragat Uygur'2, MD, https://orcid.org/0000-0002-9798-7694

Murat Yardımcı², MD, https://orcid.org/0000-0001-7062-6015

Erkan Kaya², MD, https://orcid.org/0000-0001-8235-052X

Damla Sariguney ${ }^{1}$, MD, https://orcid.org/0000-0001-5614-3017

${ }^{1}$ Department of Anesthesiology, SANKO University, Gaziantep, Turkey

${ }^{2}$ Department of Cardiovascular Surgery, SANKO University, Gaziantep, Turkey

\title{
Postoperative Early Outcomes of Conventional versus Minimally Invasive Multivessel Coronary Artery Bypass Surgery: Retrospective Study
}

\begin{abstract}
Minimally invasive coronary artery bypass grafting (CABG) is a new technique developed in recent years apart from the conventional method. Our first objective is to compare the postoperative early outcomes of conventional and minimally invasive multivessel (MIM) CABG methods, and second objective is to compare perioperative differences between two surgical techniques. This retrospective, comparative study was conducted at a university hospital with 100 patients, who underwent CABG surgery from November, 12019 to June, 12020. The data of 50 patients, who underwent MIM CABG (Group M), was certain. Among the patients operated with the conventional method (Group C), 50 patients were randomly selected from the same time period. Examination of early postoperative outcomes revealed that Group C had significantly higher intensive care unit (ICU) stay $(p=0.013)$, significantly higher mechanical ventilation time in ICU $(p<0.001)$, and significantly higher isolated systolic blood pressure ( $\mathrm{p}=0.013)$. Examination of perioperative variables revealed that Group $\mathrm{C}$ had significantly shorter duration of surgery $(\mathrm{p}<0.001)$, significantly shorter aortic cross-clamp time $(\mathrm{p}<0.001)$, significantly shorter cardiopulmonary bypass $(\mathrm{CPB})$ time $(\mathrm{p}<0.001)$, significantly lesser graft numbers $(\mathrm{p}<0.001)$, significantly lesser left internal mammary artery use ( $<<0.05)$, and significantly lesser inotropic support after CPB was discontinued $(\mathrm{p}<0.05)$. In the light of these results, MIM CABG was associated with enhanced postoperative early outcomes with prolonged surgery time compared to conventional method.
\end{abstract}

Keywords: coronary artery bypass, minimally invasive, total coronary revascularization, TCRAT, postoperative outcome.

Introduction. Coronary artery disease was seen in $7.6 \%$ of men, and $5 \%$ of women in the U.S. according to the American Heart Association [1]. Coronary artery bypass grafting (CABG) is still gold standard method in patients with diabetes or multi-vessel coronary artery disease [2, 3]. Cardiopulmonary bypass (CPB) in CABG is the most acceptable method for surgically treating coronary artery disease with a low mortality rate of $3 \%[4,5,6]$. With the advancements in thoracic surgery, minimally invasive (MI) CABG is a new technique developed in recent years apart from the conventional method [7, 8]. MI CABG, administered via small anterior thoracotomy, was introduced in Japan in the mid-1990s, but did not become a standard pro-

(C) 2021 The Authors. Published by Professional Edition Eastern Europe. This is an open access article under the CC BY-SA license (https://creativecommons.org/licenses/by-sa/4.0/). cedure due to the small surgical site and difficulty working in that area. Although MI CABG has been tested against the conventional technique and demonstrated its beneficial effects like less bleeding or no risk of sternal infection, there are still doubts about its widely accepted use and therefore it has a slow introduction to clinical practice [911]. Minimally invasive multivessel (MIM) CABG, which was presented first in 2019, is a type of MI CABG $[12,13]$. MIM CABG technique for total coronary revascularization via a left anterior thoracotomy (TCRAT) includes complete revascularization through left anterior thoracotomy with CPB. Past studies of MI and conventional CABG have resulted in conflicted findings.

\footnotetext{
*Corresponding author.

E-mail address: dreliferdogan@gmail.com (E. Erdogan).
} 
In this study, our first objective is to compare the postoperative early outcomes of conventional and MIM CABG methods, and second objective is to compare perioperative differences between two surgical techniques.

Method. This retrospective, comparative study was conducted at a university hospital. In this study, 100 patients who underwent CABG surgery from November, 1 2019 to June, 12020 in single center were reviewed. The data of 50 patients who underwent MIM CABG (Group M), was certain. Among the patients operated with the conventional method (Group C), 50 patients were randomly selected. All operations were performed by the senior cardiac surgeons. The decision on the surgery type depended on the availability of the system, surgeons' preferences, and request of the patients. All adult patients who were older than 18 years old and underwent elective CABG in cardiovascular service, were included in the study. Patients who underwent off-pump or aortic vascular operation, cardiac valve surgery, redo CABG, emergency surgical treatment, cardiac transplant; with congenital heart disease and left ventricular assist device and who were $<18$ years old were excluded from the study. This study was approved by the institutional ethics review board which waived the requirement for informed patient consent.

Preoperative, intraoperative and postoperative data of the patients were retrospectively screened from anesthesia follow-up cards and patient files. Preoperative determinants, such as gender, age, body mass index, previous myocardial infarction, left ventricular ejection fraction, functional classification of European System for Cardiac Operative Risk Evaluation (EuroSCORE), comorbid diseases such as diabetes mellitus, chronic obstructive pulmonary disease, smoking habits, liver and kidney functions.

EuroSCORE is a cardiac risk scoring system for the prediction of early mortality in cardiac surgical patients in Europe on the basis of objective risk factors [14]. Three factors were questioned in the scale: patient related, cardiac, and operation related. According to EuroSCORE, patients are evaluated in three groups: high risk ( $\geq 6$ points), moderate risk (3-5 points) and low risk (0-2 points).

Perioperative determinants, such as; surgery duration, aortic cross-clamp duration, CPB duration, number of anastomosed grafts, left internal mammary artery (LIMA) use, inotropic support after CPB was discontinued, and urine volume.

Postoperative determinants were: heart rate and blood pressure after surgery on admission to the ICU, the duration of mechanical ventilation (MV), re-intubation, ICU length of stay (LOS), hospital LOS, neurologic events (stroke, transient ischemic attack, cerebral hemorrhage and infarction), liver and kidney functions, sternum infection, complication and in-hospital mortality.

Statistical analysis. As descriptive statistics, mean and standard deviation or median and minimum-maxi- mum values for continuous variables specified by measurement, frequency and percentage values for qualitative variables will be given. In group comparisons, if the parametric test conditions are met for the continuous variables specified by the measurement, the significance test or one-way ANOVA between the two means will be used, and the Mann-Whitney U test or the Kruskal-Wallis test will be used if the parametric test conditions are not met. The Chi-square test will be used for group comparisons of qualitative variables. $\mathrm{p}<0.05$ will be considered statistically significant.

Results. Fifty patients who underwent CABG with conventional method (Group C) and 50 patients who underwent MIM CABG (Group M) were enrolled. Demographic variables are given in Table 1.

There was no significant difference in demographic variables between groups except EuroSCORE. Group M had significantly higher EuroSCORE than Group C. (0.7 \pm 0.2 vs. $1.5 \pm 0.8, \mathrm{p}<0.001$ )

Examination of perioperative variables revealed that Group C had shorter duration of surgery (180 IQR (165, $210)$ vs. 300 IQR $(270,330)$ minutes (min), p<0.001), shorter aortic cross-clamp time $(41 \pm 16$ vs. $71 \pm 17$ min, $\mathrm{p}<0.001)$, shorter CPB time $(75 \operatorname{IQR}(60,85)$ vs. 147 $\operatorname{IQR}(130,175) \mathrm{min}, \mathrm{p}<0.001)$, lesser graft numbers $(3.7 \pm$ 1 vs. $3 \pm 0.6, p<0.001$ ), lesser LIMA use ( 42 vs. $50, p<0.05$ ),

\section{Table 1}

Demographic variables of Group C and Group M

\begin{tabular}{lccc}
$\begin{array}{l}\text { Demographic } \\
\text { variables }\end{array}$ & $\begin{array}{c}\text { Group C } \\
\text { (n=50) }\end{array}$ & $\begin{array}{c}\text { Group M } \\
\text { (n=50) }\end{array}$ & p value \\
\hline Gender & & & \\
\hline Male, n (\%) & $43(86)$ & $45(90)$ & 0.75 \\
\hline Age, mean (SD) & $59(7)$ & $58(8)$ & 0.27 \\
\hline $\begin{array}{l}\text { BMI, mean (SD) } \\
\text { Preoperative myo- } \\
\text { cardial infarction, } \\
\text { n (\%) }\end{array}$ & $29(4)$ & $28,5(4)$ & 0.64 \\
\hline EF \%, mean (SD) & $56(8)$ & $6(12)$ & 0.48 \\
\hline $\begin{array}{l}\text { EuroSCORE, mean } \\
\text { (SD) }\end{array}$ & $0.7(0.2)$ & $1.5(0.8)$ & $<0.001 *$ \\
\hline DM, n (\%) & $18(36)$ & $22(44)$ & 0.54 \\
\hline COPD, n (\%) & $2(4)$ & $2(4)$ & 1 \\
\hline Smoking, n (\%) & $14(28)$ & $17(34)$ & 0.66 \\
\hline $\begin{array}{l}\text { SGPT/ALT, median } \\
\text { (IQR) }\end{array}$ & $22(17,32)$ & $28(22,33)$ & 0.11 \\
\hline $\begin{array}{l}\text { SGOT/AST, median } \\
(I Q R)\end{array}$ & $19(15,29)$ & $20(17,24)$ & 0.39 \\
\hline $\begin{array}{l}\text { Creatinine, mean } \\
\text { (SD) }\end{array}$ & $1.03(0.46)$ & $0.97(0.18)$ & 0.39 \\
\hline
\end{tabular}

BMI: Body mass index, EF: Ejection fraction, DM: Diabetes mellitus, COPD: Chronic obstructive pulmonary disease, ${ }^{*} \mathrm{p}<0.05$. 
Table 2

\section{Perioperative variables of Group C and Group M}

\begin{tabular}{lccc}
$\begin{array}{l}\text { Perioperative } \\
\text { variables }\end{array}$ & $\begin{array}{c}\text { Group C } \\
(\mathbf{n}=50)\end{array}$ & $\begin{array}{c}\text { Group M } \\
(\mathbf{n}=50)\end{array}$ & p value \\
\hline $\begin{array}{l}\text { Surgery duration, min, } \\
\text { median (IQR) }\end{array}$ & $\begin{array}{c}180 \\
(165,210)\end{array}$ & $\begin{array}{c}300 \\
(270,330)\end{array}$ & $<0.001^{*}$ \\
\hline $\begin{array}{l}\text { Aortic cross-clamp } \\
\text { duration, min, mean } \\
\text { (SD) }\end{array}$ & $41(16)$ & $74(17)$ & $<0.001^{*}$ \\
\hline $\begin{array}{l}\text { CPB duration, min, } \\
\text { median (IQR) }\end{array}$ & $75(60,85)$ & $\begin{array}{c}147 \\
(130,175)\end{array}$ & $<0.001^{*}$ \\
\hline $\begin{array}{l}\text { Graft numbers, mean } \\
\text { (SD) }\end{array}$ & $3.7(1)$ & $3(0.6)$ & $<0.001^{*}$ \\
\hline LIMA use, $n(\%)$ & $42(84)$ & $50(100)$ & $0.006^{*}$ \\
\hline Inotropic support, $n(\%)$ & $10(20)$ & $23(46)$ & $0.011^{*}$ \\
\hline Diuresis, ml, mean (SD) & $525(258)$ & $542(221)$ & 0.79 \\
*p $<0.05$. & & &
\end{tabular}

and lesser inotropic support (10 vs. $23, \mathrm{p}<0.05)$. Perioperative variables are given in Table 2 .

Examination of early postoperative outcomes revealed that Group C had significantly higher ICU length of stay (1 vs. 2 days, $p=0.013$ ), significantly higher MV time in ICU (12 vs. 8 hours $(h), p<0.001$ ), significantly higher isolated systolic blood pressure (110 vs. $99 \mathrm{mmHg}, \mathrm{p}=0.013)$, and significantly lesser ALT (normal range $=0-55)(24 \mathrm{vs}$. $30, \mathrm{p}=0.001)$ and AST (normal range $=5-34$ ) (32 vs. 42, $\mathrm{p}<0.001$ ). Postoperative variables are given in Table 3.

Postoperative complications included 3 postoperative revisions for bleeding and 4 surgical site infection in Group C, 4 surgical site infection, 1 deep venous embolism, and 1 pericardial hemorrhage in Group M.

Discussion. In this study, we compared MIM and conventional CABG method. In our study we found that MIM CABG method had enhanced postoperative early outcome compared to conventional method. First postoperative early outcome of this study was similar mean ICU LOS in Group M and Group C. However, Group C had significantly longer maximum ICU LOS in more patients. Eleven patients $(22 \%)$ in Group C had prolonged ICU stay between $48 \mathrm{~h}$ and 30 days. Group M had 4 patients (2\%) with prolonged ICU LOS between $48 \mathrm{~h}$ and 19 days. Our data are consistent with Hammermeister et al. who found that $20 \%$ of the open heart surgery patients had prolonged ICU LOS [15]. Baishya et al. compared 25 patients with MI method and 25 patients with conventional method. They showed shorter ICU stay (1.7 vs. 2.2 days) in MI group [16]. Previous studies noted prolonged ICU LOS up to $45 \%$ of the patients with a wide range between $48 \mathrm{~h}$ to 10 days [17-23]. In our study, the number of ICU days was more than that in previous studies. Well known risk factors of prolonged ICU stay after cardiac surgery are: advanced age, female gender, congestive heart failure, respiratory insufficiency,
Table 3

Postoperative variables of Group C and Group M

\begin{tabular}{|c|c|c|c|}
\hline $\begin{array}{l}\text { Postoperative } \\
\text { variables }\end{array}$ & $\begin{array}{c}\text { Group } C \\
(n=50)\end{array}$ & $\begin{array}{c}\text { Group M } \\
(n=50)\end{array}$ & $p$ value \\
\hline $\begin{array}{l}\text { ICU Heart rate, mean } \\
\text { (SD) }\end{array}$ & $84(16)$ & $84(10)$ & 0.99 \\
\hline $\begin{array}{l}\text { ICU Systolic BP, mean } \\
\text { (SD) }\end{array}$ & $110(26)$ & $99(15)$ & $0.013^{*}$ \\
\hline $\begin{array}{l}\text { ICU Diastolic BP, mean } \\
\text { (SD) }\end{array}$ & $55(11)$ & $55(10)$ & 0,844 \\
\hline $\begin{array}{l}\text { MV Duration, hr, me- } \\
\text { dian (IQR) }\end{array}$ & $12(10,16)$ & $8(7,12)$ & $<0.001^{*}$ \\
\hline Re-intubation, n (\%) & $2(4)$ & $2(4)$ & 1 \\
\hline $\begin{array}{l}\text { ICU LOS, day, median } \\
\text { (IQR) }\end{array}$ & $1(1,2)$ & $2(1,2)$ & \\
\hline maximum & 30 & 19 & $0.017^{*}$ \\
\hline $\begin{array}{l}\text { Hospital LOS, day, } \\
\text { median (IQR) }\end{array}$ & $6(6,7)$ & $6(5,7)$ & \\
\hline maximum & 40 & 19 & 0.3 \\
\hline $\begin{array}{l}\text { Neurologic event, } n \\
\text { (\%) }\end{array}$ & $4(8)$ & $1(2)$ & 0.36 \\
\hline Creatinin, mean (SD) & $1.06(0.5)$ & $1.02(0.2)$ & 0.54 \\
\hline $\begin{array}{l}\text { SGPT/ALT, median } \\
\text { (IQR) }\end{array}$ & $24(18,28)$ & $30(24,43)$ & $0.001^{*}$ \\
\hline $\begin{array}{l}\text { SGOT/AST, median } \\
(\mathrm{IQR})\end{array}$ & $32(26,37)$ & $42(33,63)$ & $<0.001^{*}$ \\
\hline Complication, n (\%) & $7(14)$ & $6(12)$ & 1 \\
\hline $\begin{array}{l}\text { Hospital mortality, } \\
\text { n (\%) }\end{array}$ & $3(6)$ & $1(2)$ & 0.61 \\
\hline
\end{tabular}

$* \mathrm{p}<0.05$.

vascular disease, DM, renal failure, arrhythmia, inotropic agent support, intra-aortic balloon pump requirements, and reoperation [19-24]. Bashour et al. reported that prolonged ICU stay was associated with COPD [24]. In Group C, 2 patients with COPD had more than $48 \mathrm{~h}$ ICU LOS. However, 2 patients with COPD in Group M had less than $48 \mathrm{~h}$ ICU LOS. In our study, patients with COPD had less ICU LOS with MIM method. Similar to our results; Schmitto et al., who searched literature between 1995-2010, and Merk et al., who evaluated 2364 patients retrospectively, noted enhanced postoperative recovery with MI method [7, 8].

The second postoperative early outcome of this study was that Group C had longer duration of MV in ICU than Group M (12 h vs. $8 \mathrm{~h}$ ) with re-intubation of 2 patients in each group. Similar to our results, Baishya et al. (4 vs. $8 \mathrm{~h}$ ) and Poston et al. ( 4 vs. $12 \mathrm{~h}$ ) found shorter duration of MV in ICU in MI group compared to conventional group [16, 25]. García-Delgado et al. reported that CPB causes lung injury with an intense systemic inflammatory syndrome and increased lung capillary permeability. In these patients, the duration of extubation and mechanical ventilation was associated with prolonged ICU and hospital LOS. They reported that less than $10 \%$ of cardiac surgery patients re- 
quire prolonged $\mathrm{MV}$, which is more than $12 \mathrm{~h}$ [26]. In our study, 23 patients (46\%) in Group C and 10 patients (20\%) in Group M had more than $12 \mathrm{~h}$ MV requirement. Factors that predict prolonged MV are: age above 65 years, female sex, renal or lung failure, history of stroke, emergency surgery, perioperative angina and infarction, ejection fraction less than 30\%, CPB for more than 77-91 min, clamping time more than $60 \mathrm{~min}$, bleeding, and postoperative oxygenation [27-30].

The other significantly different postoperative early outcome was isolated systolic blood pressure. Group C patients had higher isolated systolic blood pressure than those in Group M. We did not have data of postoperative pain, but this was likely due to the sternotomy pain. Similar results were obtained by Babliak et al. who showed decreased postoperative pain and earlier mobilization with arm movements in MIM CABG [13]. Baishya et al. found lower VAS scores and analgesic requirement in MI group compared to conventional group after surgery [14]. In contrast to our findings, Lichtenberg et al. showed more pain in MI than conventional group [31].

The last significantly different postoperative early outcome was increased ALT and AST in each group. Group $M$ had significantly higher ALT and AST than Group C. McSweeney et al. assessed gastrointestinal complications after CPB surgery, and similarly to our results they showed postoperative increase in ALT and AST levels [32].

As for perioperative variables, our study showed that Group M had longer surgery, aortic cross-clamp, and CPB time. Although MI method has several benefits, it was also associated with increased technical difficulty posed by the reduced surgical field and longer duration of surgery. Similar to our results, Baishya et al. found significantly longer surgery duration in MI CABG [16].

In preoperative variables, Group $\mathrm{M}$ had significantly higher EuroSCORE than Group C (0.7 vs. 1.5). In our institution MIM CABG technique was used in some of the highrisk patients at the discretion of the surgeons or upon the request of the patients. The EuroSCORE risk classification is important in postoperative complications and ICU and hospital LOS in cardiac surgeries. Patients with high EuroSCORE have a longer ICU LOS due to more frequent complications resulting from comorbidities [33]. In our study we found that EuroSCORE of Group M was higher than that of Group C. It was seen that our surgeons preferred to use MIM CABG technique in high-risk patients.

In the light of these results MIM CABG is associated with improved postoperative early outcomes compared to conventional method. MIM CABG could be a true alternative for high-risk patients. MIM CABG had short MV duration, maximum ICU LOS, and hospital LOS. COPD patients had less ICU LOS with MIM CABG technique. But also, due to the small surgical site and difficulty working in that area, MIM CABG group was associated with long surgery time, aortic cross-clamp time, CPB time and more grafts, and high inotropic support. Additional studies are needed to confirm enhanced postoperative early outcome in MIM CABG method compared to conventional method.

Limitations. Our study had several limitations. It was a retrospective study with limited number of patients in the groups due to the performed surgeries in our hospital. Other limitation was the fact that we were able to record only ALT and AST levels, other gastrointestinal system markers were not listed in our routine blood tests. Lastly, MIM technique is a new technique with a few studies in the literature. Therefore, we also discussed general MI technique in our study.

\section{Disclosures}

There is no conflict of interest.

\section{References}

1. Mozaffarian D, Benjamin EJ, Go AS, Arnett DK, Blaha MJ, Cushman M, et al. Executive summary: Heart disease and stroke statistics--2016 update: A report from the American Heart Association. Circulation. 2016;133(4):447-54. https://doi.org/10.1161/CIR.0000000000000366

2. Mohr FW, Morice MC, Kappetein AP, Feldman TE, Ståhle E, Colombo A, Mack MJ, Holmes DR Jr, Morel MA, Van Dyck N, Houle VM, Dawkins KD, Serruys PW. Coronary artery bypass graft surgery versus percutaneous coronary intervention in patients with three-vessel disease and left main coronary disease: 5-year follow-up of the randomised, clinical SYNTAX trial. Lancet. 2013;381(9867):629-38. https://doi.org/10.1016/S0140-6736(13)60141-5

3. Farkouh ME, Domanski M, Sleeper LA, Siami FS, Dangas G, Mack M, et al. Strategies for multivessel revascularization in patients with diabetes. N Engl J Med. 2012;367(25):237584. https://doi.org/10.1056/NEJMoa1211585

4. Penttilä HJ, Lepojärvi MV, Kiviluoma KT, Kaukoranta PK, Hassinen IE, Peuhkurinen KJ. Myocardial preservation during coronarysurgerywithand withoutcardiopulmonary bypass. Ann Thorac Surg. 2001;71(2):565-71. https://doi. org/10.1016/s0003-4975(00)02002-6

5. Gundry SR, Romano MA, Shattuck OH, Razzouk AJ, Bailey LL. Seven-year follow-up of coronary artery bypasses performed with and without cardiopulmonary bypass. J Thorac Cardiovasc Surg. 1998;115(6):1273-7; discussion 1277-8. https://doi.org/10.1016/S0022-5223(98)70209-0

6. Fitzgibbon GM, Kafka HP, Leach AJ, Keon WJ, Hooper GD, Burton JR. Coronary bypass graft fate and patient outcome: angiographic follow-up of 5,065 grafts related to survival and reoperation in 1,388 patients during 25 years. J Am Coll Cardiol. 1996;28(3):616-26. https://doi. org/10.1016/0735-1097(96)00206-9

7. Schmitto JD, Mokashi SA, Cohn LH. Minimally-invasive valve surgery. J Am Coll Cardiol. 2010;56(6):455-62. https://doi.org/10.1016/j.jacc.2010.03.053

8. Merk DR, Lehmann S, Holzhey DM, Dohmen P, Candolfi P, Misfeld M, Mohr FW, Borger MA. Minimal invasive aortic valve replacement surgery is associated with improved survival: a propensity-matched comparison. Eur J Cardiothorac Surg. 2015;47(1):11-7. https://doi.org/ 10.1093/ejcts/ezu068 
9. Lapierre H, Chan V, Sohmer B, Mesana TG, Ruel M. Minimally invasive coronary artery bypass grafting via a small thoracotomy versus off-pump: a case-matched study. Eur J Cardiothorac Surg. 2011;40(4):804-10. https://doi. org/10.1016/j.ejcts.2011.01.066

10. Ruel M, Une D, Bonatti J, McGinn JT. Minimally invasive coronary artery bypass grafting: is it time for the robot? Curr Opin Cardiol. 2013;28(6):639-45. https://doi. org/10.1097/HCO.0b013e3283653fd1

11. Anastasiadis K, Asteriou C, Deliopoulos A, Argiriadou H, Karapanagiotidis G, Antonitsis $\mathrm{P}$, Grosomanidis V, Misias G, Papakonstantinou C. Haematological effects of minimized compared to conventional extracorporeal circulation after coronary revascularization procedures. Perfusion. 2010;25(4):197-203. https://doi. org/10.1177/0267659110373840

12. Babliak O, Demianenko V, Melnyk Y, Revenko K, Pidgayna L, Stohov 0 . Complete Coronary Revascularization via Left Anterior Thoracotomy. Innovations (Phila). 2019;14(4):330-41. https://doi. org/10.1177/1556984519849126

13. Babliak O, Demianenko V, Melnyk Y, Revenko K, Pidgayna L, Stohov 0. Total coronary revascularization via left anterior thoracotomy: Practical aspects. Multimed Man Cardiothorac Surg. 2019;2019. https://doi.org/10.1510/ mmcts.2019.031

14. Nashef SA, Roques F, Michel P, Gauducheau E, Lemeshow S, Salamon R. European system for cardiac operative risk evaluation (EuroSCORE). Eur J Cardiothorac Surg. 1999;16(1):9-13. https://doi.org/10.1016/s10107940(99)00134-7

15. Hammermeister KE, Burchfiel C, Johnson R, Grover FL. Identification of patients at greatest risk for developing major complications at cardiac surgery. Circulation. 1990;82(5 Suppl):380-9.

16. Baishya J, George A, Krishnamoorthy J, Muniraju G, Chakravarthy M. Minimally invasive compared to conventional approach for coronary artery bypass grafting improves outcome. Ann Card Anaesth. 2017;20(1):57-60. https://doi.org/10.4103/0971-9784.197837

17. van Mastrigt GA, Heijmans J, Severens JL, Fransen EJ, Roekaerts P, Voss G, Maessen JG. Short-stay intensive care after coronary artery bypass surgery: randomized clinical trial on safety and cost-effectiveness. Crit Care Med. 2006;34(1):65-75. https://doi.org/10.1097/01. ccm.0000191266.72652.fa

18. Bucerius J, Gummert JF, Walther T, Doll N, Falk V, Schmitt DV, Mohr FW. Predictors of prolonged ICU stay after onpump versus off-pump coronary artery bypass grafting. Intensive Care Med. 2004;30(1):88-95. https://doi. org/10.1007/s00134-003-1950-5

19. Heimrath OP, Buth KJ, Légaré JF. Long-term outcomes in patients requiring stay of more than 48 hours in the intensive care unit following coronary bypass surgery. J Crit Care. 2007;22(2):153-8. https://doi.org/10.1016/j. jcrc.2006.09.009

20. Hein OV, Birnbaum J, Wernecke K, England M, Konertz W, Spies C. Prolonged intensive care unit stay in cardiac surgery: risk factors and long-term-survival. Ann Thorac
Surg. 2006;81(3):880-5. https://doi.org/10.1016/j. athoracsur.2005.09.077

21. Doering LV, Esmailian F, Imperial-Perez F, Monsein S. Determinants of intensive care unit length of stay after coronary artery bypass graft surgery. Heart Lung. 2001;30(1):9-17. https://doi.org/10.1067/ mhl.2001.112502

22. De Cocker J, Messaoudi N, Stockman BA, Bossaert LL, Rodrigus IE. Preoperative prediction of intensive care unit stay following cardiac surgery. Eur J Cardiothorac Surg. 2011 Jan;39(1):60-7. https://doi.org/10.1016/j. ejcts.2010.04.015

23. Almashrafi A, Elmontsri M, Aylin P. Systematic review of factors influencing length of stay in ICU after adult cardiac surgery. BMC Health Serv Res. 2016;16:318. https://doi. org/10.1186/s12913-016-1591-3

24. Bashour CA, Yared JP, Ryan TA, Rady MY, Mascha E, Leventhal MJ, Starr NJ. Long-term survival and functional capacity in cardiac surgery patients after prolonged intensive care. Crit Care Med. 2000;28(12):3847-53. https://doi.org/10.1097/00003246-20001200000018

25. Poston RS, Tran R, Collins M, Reynolds M, Connerney I, Reicher B, Zimrin D, Griffith BP, Bartlett ST. Comparison of economic and patient outcomes with minimally invasive versus traditional off-pump coronary artery bypass grafting techniques. Ann Surg. 2008;248(4):638-46. https://doi.org/10.1097/SLA.0b013e31818a15b5

26. García-Delgado M, Navarrete-Sánchez I, Colmenero M. Preventing and managing perioperative pulmonary complications following cardiac surgery. Curr Opin Anaesthesiol. 2014;27(2):146-52. https://doi. org/10.1097/AC0.0000000000000059

27. Naughton C, Reilly N, Powroznyk A, Aps C, Hunt T, Hunter D, Parsons RS, Sherry E, Spackman D, Wielogorski A, Feneck RO. Factors determining the duration of tracheal intubation in cardiac surgery: a single-centre sequential patient audit. Eur J Anaesthesiol. 2003;20(3):225-33. https://doi.org/10.1017/s0265021503000383

28. Sato M, Suenaga E, Koga S, Matsuyama S, Kawasaki H, Maki F. Early tracheal extubation after on-pump coronary artery bypass grafting. Ann Thorac Cardiovasc Surg. 2009;15(4):239-42. PMID: 19763055.

29. Cislaghi F, Condemi AM, Corona A. Predictors of prolonged mechanical ventilation in a cohort of 5123 cardiac surgical patients. Eur J Anaesthesiol. 2009;26(5):396-403. https:// doi.org/10.1097/EJA.0b013e3283232c69

30. Cislaghi F, Condemi AM, Corona A. Predictors of prolonged mechanical ventilation in a cohort of 3,269 CABG patients. Minerva Anestesiol. 2007;73(12):615-21. PMID: 18046291

31. Lichtenberg A, Hagl C, Harringer W, Klima U, Haverich A. Effects of minimal invasive coronary artery bypass on pulmonary function and postoperative pain. Ann Thorac Surg. 2000;70(2):461-5. https://doi.org/10.1016/s00034975(00)01505-8

32. McSweeney ME, Garwood S, Levin J, Marino MR, Wang SX, Kardatzke D, Mangano DT, Wolman RL; Investigators of the Ischemia Research and Education Foundation and 
the Multicenter Study of Perioperative Ischemia Research Group. Adverse gastrointestinal complications after cardiopulmonary bypass: can outcome be predicted from preoperative riskfactors? Anesth Analg. 2004;98(6):1610-7. https://doi.org/10.1213/01.ANE.0000113556.40345.2E
33. Tunç M, Şahutoğlu C, Karaca N, Kocabaş S, Aşkar FZ. Risk Factors for Prolonged Intensive Care Unit Stay After Open Heart Surgery in Adults. Turk J Anaesthesiol Reanim. 2018;46(4):283-91. https://doi.org/10.5152/ TJAR.2018.92244

\section{Ранні післяопераційні результати традиційного або мінімально інвазивного багатосудинного аорто-коронарного шунтування: ретроспективне дослідження}

Elif Erdogan ${ }^{1 *}$, MD, https://orcid.org/0000-0002-2206-9928

Gokhan Gokarslan², MD, https://orcid.org/0000-0003-1730-0993

Feragat Uygur'2, MD, https://orcid.org/0000-0002-9798-7694

Murat Yardımc ${ }^{2}$, MD, https://orcid.org/0000-0001-7062-6015

Erkan Kaya ${ }^{2}$, MD, https://orcid.org/0000-0001-8235-052X

Damla Sariguney ${ }^{1}$, MD, https://orcid.org/0000-0001-5614-3017

${ }^{1}$ Кафедра анестезіології, Університет САНКО, м. Газіантеп, Туреччина

${ }^{2}$ Кафедра серцево-судинної хірургії, Університет САНКО, М. Газіантеп, Туреччина

Резюме. Мінімально інвазивне аорто-коронарне шунтування (АКШ) - нова методика, розроблена нещодавно поряд із традиційним методом. Нашою першою метою $є$ порівняння ранніх післяопераційних результатів традиційного або мінімально інвазивного багатосудинного (МІБ) АКШ, друга мета полягає у порівнянні післяопераційних розбіжностей між двома хірургічними методиками. Це ретроспективне порівняльне дослідження було проведене в університетській лікарні за участю 100 пацієнтів, яким виконували АКШ у період з 1 листопада 2019 по 1 червня 2020 року. Дані щодо 50 пацієнтів, у яких проводили МІБ АКШ (група М), були достовірними. Серед пацієнтів, яким виконували операцію з використанням традиційної методики (група С), були випадковим чином вибрані 50 пацієнтів за той самий період часу. Дослідження ранніх післяопераційних результатів виявило, що серед пацієнтів групи С значно більшими були тривалість перебування у відділенні інтенсивної терапії (BIT) $(\mathrm{p}=0,013)$, тривалість штучної вентиляції легень у BIT $(\mathrm{p}<0,001)$ та значення систолічного артеріального тиску $(\mathrm{p}=0,013)$. Дослідження періопераційних змінних виявило у пацієнтів групи С значно меншу тривалість хірургічного втручання ( $<<0,001)$, значно менший час перетискання артерії $(\mathrm{p}<0,001)$, значно менший час штучного кровообігу $(\mathrm{p}<0,001)$, значно меншу кількість трансплантатів $(\mathrm{p}<0,001)$, значно меншу частоту використання лівої внутрішньої грудної артерії $(\mathrm{p}<0,05)$ та значно меншу інотропну підтримку після припинення штучного кровообігу $(\mathrm{p}<0,05)$. У світлі цих результатів МІБ АКШ асоціювалося з кращими ранніми післяопераційними результатами на тлі більшої тривалості хірургічного втручання порівняно з традиційним методом.

Ключові слова: аорто-коронарний шунт, мінімально інвазивний, повна коронарна реваскуляризація, повна коронарна реваскуляризація через передню торакотомію.

Стаття надійшла в редакцію 09.11.2021 р. 